Article

\title{
Children's Participation, Progressive Autonomy, and Agency for Inclusive Education in Schools
}

\author{
Marta B. Esteban \\ Institute for Educational Research, University of Barcelona, Spain; m.esteban@ub.edu
}

Submitted: 29 October 2021 | Accepted: 21 December 2021 | Published: 20 April 2022

\begin{abstract}
Whereas children's agency and their right to civic participation have been extensively discussed in childhood studies, especially within sociology, their presence in pedagogical studies is still scarce. We intend to contribute to tentatively plugging that gap by analysing the need for a change of perspective in school settings based on acknowledging children as participatory social actors. We are committed to an epistemological broadening of the expression "inclusive education" that complements the traditional and necessary meaning of "reaching to all learners"; a broadening grounded on the configuration of intergenerational relationships in which children participate in schools as learners and partners, as agents who are part of their community and take part in it. Schools are thus transformed into inclusive democratic educational communities or fellowships that include children in the decision-making on those aspects that affect them, according to their progressive autonomy, while validating their knowledge and experiences. The article is framed on the sustainable development goals (SDG), specifically on SDG no.4, to ensure inclusive, equitable, and quality education, and SDG no.16, which urges to promote just, peaceful, and inclusive societies and the consolidation of institutions. Our stance is that a significant step forward to achieving these goals is that schools should prepare for life in democracy by being experienced and run democratically. This involves children's gradual participation in school management, from the micro to the macro level. To this end, we focus on three key elements: children's rights to participation, the principle of progressive autonomy, and acknowledging children's agency in schools.
\end{abstract}

\section{Keywords}

agency rights; children's agency; children's participation; children' rights; evolving capacities; inclusive education; progressive autonomy; sustainable development goals

Issue

This article is part of the issue "Promoting Social Inclusive Experiences in Uncertain Times" edited by Ana Belén Cano-Hila (University of Barcelona).

(C) 2022 by the author(s); licensee Cogitatio (Lisbon, Portugal). This article is licensed under a Creative Commons Attribution 4.0 International License (CC BY).

\section{Introduction}

In this article, a series of reflections on the concept of educational inclusion and how the democratisation of school life can help amplify the epistemologies surrounding the term are presented. To this end, we suggest a complementary approach to its scope based on the observation of three key elements: children's right to participation, support and accompaniment of children's progressive autonomy, and the recognition of their agency. Whereas children's agency and their right to civic participation have been extensively discussed in childhood studies, especially within sociology, their presence in pedagogical studies is still scarce. We intend to contribute to tentatively plugging that gap.

A relevant backdrop for these reflections is the United Nations 2030 agenda for sustainable development and its sustainable development goals (SDGs), a global roadmap approved by 197 countries in November 2015. Specifically, we look at SDG no. 4 towards inclusive and equitable quality education and lifelong learning for all. According to UNESCO (2017, p. 10), SDG no. 4 "is both a goal in itself and a means for attaining all other SDGs." SDG no. 16 is another benchmark. This goal urges 
to promote just, peaceful, and inclusive societies and the consolidation of their institutions. Target 16.7 of this goal calls for developing effective, accountable, and transparent institutions at all levels (United Nations, 2015). From these premises, this article holds that the school institution can contribute to the achievement not only of SDG no. 4 but also of SDG no. 16 if it is democratised and children are recognised not only as learners but also as participatory social actors of the educational community.

Also considered are articles 12.1 to 15.1 of the 1989 United Nations Convention on the Rights of the Child (UNCRC; United Nations, 1989), on the participatory rights of children, as well as the United Nations (2009) General Comment no. 12 on the right of the child to be heard. This context also comprises: article 24.1 of the Charter of Fundamental Rights of the European Union (2000) on the right of children to express themselves freely and be considered in accordance with their age and maturity; the EU agenda for the rights of the child aiming to inform children, families, and teachers about children's rights after finding, between 2008 and 2009 , that $76 \%$ of children did not know about their rights (European Commission, 2011); and the Bucharest EU Children's Declaration (Romanian Children's Board, Children and Experts From the EU, 2019) in which we read:

School is the place where we receive information, acquire knowledge, and develop skills. Therefore, we believe that it should become a place where we learn about participation and can exercise participation outside our family. This can only happen if, in school, we are involved in the education process as partners. (p. 2)

While the EU agenda for the rights of the child (European Commission, 2011) informed that $76 \%$ of children were not aware of being subjects of rights, the Evaluation of Legislation, Policy, and Practise on Child Participation in the European Union report (Day et al., 2015, p. 33) expressed concern that the "UNCRC and the article 12 do not feature prominently within the initial teacher training." In this regard, UNICEF Spain reported that $88 \%$ of professionals working with children were unaware of the UNCRC basics. More recent research (see Janta et al., 2021) does not yield more promising data. In the focus groups carried out in various European countries, it was found that, although children were generally aware of their rights, they didn't feel included in decisionmaking processes on matters affecting them. One of the identified barriers for the inclusion of children as active members of their communities was the attitude of adults: "Societal attitudes of not seeing children as competent social actors who can contribute to decisions in a meaningful way is still common" (Janta et al., 2021, p. 69). These attitudinal barriers represent another critical backbone of the reflections presented in the following sections.

\section{Complementing the Epistemologies of Inclusive Education: Children as Learners and Partners}

In this section, we seek to amplify the concept of "inclusive education," which can take different definitions (Echeita Sarrionandía \& Ainscow, 2011). However, it is generally understood as the reception of student diversity in educational settings. The aim is to raise educational inclusion to the recognition of children-of all children regardless of their circumstances-not only as learners but as partners, namely, as participatory social actors of the school community whose voices are heard and heeded, and who participate in the decision-making based on their rights to participation and according to their progressive autonomy.

As Messiou (2018) points out, the concept of "inclusive education" gained international relevance since the adoption of the Salamanca Statement and Framework for Action on Special Needs Education (UNESCO \& Ministry of Education and Science Spain, 1994). In the document, we read: "These documents are informed by the principle of inclusion, by recognition of the need to work towards 'schools for all' -institutions which include everybody, celebrate differences, support learning, and respond to individual needs" (UNESCO \& Ministry of Education and Science Spain, 1994, p. iii). Since then, such an understanding of "inclusive education" has been echoed in various reports and conventions (UNESCO, 2001, 2005, 2008).

The Organisation of Ibero-American States for Education, Science and Culture (OEI) defines "inclusive education" as "schools for all, without exclusion, in which students from different social conditions, from different cultures and with different abilities and interests live and learn together, from the most able to those with disabilities" (OEI, 2010, p. 108). This document provides a glimpse of an enhancement of the conceptualisation of "inclusive education" since it states that "an inclusive school is, in essence, a democratic and pluralistic school that welcomes all people in the community...and transforms its culture, organisation, and pedagogical proposal so that all students participate and succeed in their learning" (OEI, 2010, p. 108).

The amplification of the term we propose necessarily involves recognising children's right to education and participation. We suggest a definition of educational inclusion that implies the inclusion of all diversities along with the recognition of children's rights to participation in those issues that affect and are of interest to them at school. This second notion of educational inclusion is the main contribution we are making: an inclusion that involves listening and addressing children's voices and points of view (De Haro et al., 2019; Echeita Sarrionandía \& Ainscow, 2011; Farré Riera, 2021; Feu Gelis \& Torrent Font, 2018; Sañudo \& Susinos, 2018) while making them gradually participants in decisionmaking processes according to their progressive autonomy; an inclusion that is in line with children's "desires, 
interests, experiences and knowledge" (Moreno Gómez et al., in press). Under this principle, children are not regarded as passive recipients of services and rights but as agents and subjects of rights involved in the school community as participatory social actors, together with teachers, other staff, and families.

This right to participation, analysed in further detail in the following section, entails recognising children as subjects of rights within the pedagogical relationship (Sañudo \& Susinos, 2018). As a set of rights recognised in the UNCRC, student participation in schools is but a recognition of a fundamental right that in no case should be presented "as a concession tinged with a paternalistic attitude that we adults make to the youngest" (Feu Gelis \& Torrent Font, 2018, p. 44). In this regard, Echeita Sarrionandía and Ainscow (2011, p. 33) note that educational inclusion in schools should focus on the "presence, participation and achievement of students," understanding participation as the incorporation of the points of view or voices of students, based on the establishment of schools that are thought, organised, and articulated from a genuinely democratic culture (Apple \& Beane, 2007). That is, building inclusive educational democratic communities-or fellowships-where students and teachers work together as partners in their relationships (Fielding, 2012).

In short, we propose a redefinition of educational inclusion as the participation of children as learners-partners in the pedagogical relationship within schools, following their progressive autonomy and evolving capacities, consistent with the recognition of their agency.

\section{Participation Rights: Cornerstone of Inclusive Educational Democratic Communities or Fellowships}

In this section, we analyse how children's participation in schools can promote inclusive democratic educational communities or fellowships, which Fielding (2012, p. 55) describes as communities built on a relational vision of democracy "which presumes, nurtures and anticipates more inclusive and more generously conceived forms of human sociality." This participation responds to a legal imperative since it is a subjective right granted to children in the UNCRC, and it is one of the conditions set out in this text for children to be included as participatory social actors and valid stakeholders in their educational communities.

Our starting point is a conception of child participation as a pedagogical practice and an educational ideal (Andreasen Lysgaard \& Simovska, 2016), as well as the "notion that children have the right to express their views and have them taken into account on all matters that concern them, in accordance with their age and maturity" (Janta et al., 2021, p. II). Likewise, we understand child participation in schools as involving pupils as partners (Romanian Children's Board, Children and Experts From the EU, 2019) in school decision-making processes (Olufisayo John-Akinola et al., 2014) regardless of personal circumstances. We are confident that all children can and should participate and that no personal circumstance is an obstacle as long as means are adapted accordingly, and their actual capabilities recognised, rather than focusing on those they might lack, as is often the case.

The above should be materialised from the recognition that people who have not reached the age of 18 are citizens of the present (Esteban Tortajada \& Novella Cámara, 2018) whose capacities are "differently equal" (Moosa-Mitha, 2005, p. 386) to those of adults, and should not, therefore, be undervalued and disregarded (Liebel, 2015). From this perspective, the concept of participation most used in schools, linked to class attendance or interactivity in the activities proposed by teachers to increase their motivation to learn (Simovska, 2007, 2011), is broadened to the construction of inclusive democratic educational communities or fellowships in which children's status as partners and their right to express themselves, to be heard and to participate in decision-making, according to their capabilities, autonomy and maturity, are recognised and respected.

As discussed in Section 2, participation in decisionmaking refers to the inclusion of children as participatory social actors in different areas and dimensions of school organisation. According to Fielding (2011), schools can be organised based on a neoliberal or market logic or a person-centred model. The first model encourages the construction of a highly individualistic identity and connects to children's future labour market. Here we will not debate the necessity, or otherwise, of integrating elements of this approach into schools. Instead, we highlight that the person-centred democratic community model promotes children's participation from a relational perspective in which student participation is seen, in partnership with the school's personnel, as "a full range of everyday opportunities in which young people can listen and be listened to, make decisions and take responsibility for both the day-to-day and for creating a better future" (Fielding, 2011, p. 50).

Building inclusive, person-centred democratic educational communities or fellowships require the recognition of children as partners. Thus, the concept of recognition is central to the transformation of schools. Thomas (2012, p. 464) discusses how Honneth's theory of recognition, and despite the author's reluctance to acknowledge "children's agency, sociality and citizenship" can be helpful to analyse the place that children should occupy in society and, consequently, in schools. Thomas (2012, p. 458), in line with the position of this article, maintains:

(1) that children do belong to the class of morally responsible persons, are therefore rights-bearers and are entitled to respect; and (2) that children are people with talents and capabilities, who contribute in a variety of ways to society and culture, and so are deserving of esteem. 
The author argues that Honneth's model invites us to consider children as subjects who care and give affection, as subjects of rights, as subjects who respect the rights of others, and as members of their communities. As Honneth and Margalit (2001) and Honneth (2012) state, children will acquire a positive relationship with themselves and others if they are recognised as socially valid and responsible actors of the communities they belong and take part. This should also be interpreted within the school environment. To this element of participation as a critical component for educational inclusion, we add, as discussed in the following sections, the accompaniment of children's progressive autonomy and the recognition of their agency.

\section{Progressive Autonomy: Gradually Increased Participation According to Children's Evolving Capacities}

The second element that may contribute to the transformation of schools into inclusive democratic educational communities or fellowships is the accompaniment of children's progressive autonomy and their gradual participation in school decision-making. Discussing children's autonomy is always an opportunity to pay tribute to Janusz Korczak. Korczak, a trailblazer in the advocacy for children's rights, held that, despite children's evident lack of experience and knowledge, and their dependence on adults, they should be included and participate in decision-making on matters that affect them by establishing adult-child relationships that give "the child full autonomy in social and political matters" (Liebel, 2019, p. 187). The Polish-born doctor and pedagogue introduced into the collective mind the idea that the protagonism and autonomy of children should be at the centre of education, based on children's responsibility for their own decisions.

The expression "progressive autonomy" is a critical aspect of the UNCRC (Díaz Arce, 2019; Lansdown, 2005; Uriarte, 2013) expressed in terms of "evolving capacities," which appears in articles 5 and 12.1 of the UNCRC. These articles state that the child shall receive appropriate direction and guidance in the exercise of their rights, and that the child shall be able to express their views freely and that these shall be considered following their evolving capacities. In short, the UNCRC argues that children's exercise of rights is progressive. In this regard, Lansdown $(2005$, p. 19) cautions that this principle should not be understood from a universal approach of a homogeneous succession of stages since "children live in diverse environments and cultures and are faced with different life experiences, acquire competencies at different ages, and their acquisition varies according to circumstances."

This last point Lansdown warns us about is critical for this article. Some of the aspects that arise most concern when it comes to including children as social agents with the capacity to make decisions in an informed, respon- sible manner are linked to their capacities-attention to the multiplicity of diversities in the school itself-to gender equity, the inclusion of racialised children or the fear that only those considered "more capable" will end up participating. Unquestionably, these elements can limit or hinder opportunities; however, this epistemological shift could offer solutions-without falling into the ambush of giving straightforward answers to highly complex matters - to the particulars exposed.

The reasonable fear that only those considered "more able" will end up participating, that there will be no tangible gender equity in decision-making, that racialised children will have fewer opportunities, to give but a few examples, can be transcended when a progressive autonomy approach is followed. This approach facilitates children's recognition of who they are and what they do, rather than recognising them from the prevailing social and cultural representations. It is an enabling approach that discards measurement patterns and allows each child to participate according to their possibilities at any given moment, based on trust and respect, or, as Van Manen (2016) would say, pedagogical loving care, trustful hope, and responsibility.

In the perspective of this manuscript, autonomy is conceptualised as the freedom that enables individuals to express their will and make decisions about aspects that affect them, inescapably linked to personal responsibility (Santana Ramos, 2014). Personal responsibility is a pivotal element, signified as personal moral responsibility, contributing to the transcendence of prevailing individualism in our current western societies. In this sense, Molins i Paronella (2020) forewarns of the unavoidable infantilisation of our societies when autonomy is promoted based on individual and individualistic freedom instead of fostering an autonomy built on accountability, responsibility, and otherness. As Mèlich and Bárcena (1999) observed, the modern conception of autonomy leaves the other faceless, voiceless. It is precisely this conception that western societies shall overcome.

These processes of acquiring moral responsibility and progressive autonomy are linked to no less than the guiding purpose of education: the full development of the personality, that is, the awareness of one's values and preferences. As Santana Ramos (2014, p. 107) points out, the educational purpose for the full development of the personality is, ultimately, "the consecration of the principle of individual autonomy." This goal is included in the Universal Declaration of Human Rights (United Nations, 1948) in articles 26.2 and 29.1, which state, respectively, "education shall be directed to the full development of the human personality and to the strengthening of respect for human rights and fundamental freedoms," and "everyone has duties to the community in which alone the free and full development of his personality is possible." It is also reflected in the constitutions of democratic states such as Germany (article 2.1), Italy (article 3), Portugal (article 26), and Spain (article 26.2; Santana Ramos, 2014). 
The articulation of the gradual nature of participation in schools should have a collaborative character between learner-partners, teachers and other adult staff and be rooted in the implicative action of children from an early age. We propose that this participatory action should take place gradually, starting with spaces for joint deliberation in the context of class-group management and progressively moving towards the co-design of the curriculum and school spaces. This should come about through progressively shared leadership that would allow children's increased accountability and responsibility, culminating in the participation of leaners-partners in the school's governance not only from a representative democracy model but from a participatory one. All in all, a progressive partnership and co-leadership between children and adults. Figure 1 shows this gradual participation of children in schools as inclusive democratic educational communities or fellowships following their progressive autonomy.

This accompaniment and promotion of the progressive autonomy of children in schools linked to the development of their moral personality and rooted in accountability, responsibility and otherness should be one of the backbones of democratic-community life in the school institution if it is to be truly inclusive in the terms set out in Section 2. As Lansdown (2005, p. ix) states, "as children acquire enhanced competencies, there is a reduced need for direction and a greater capacity to take responsibility for decisions affecting their lives." In schools, this accompaniment of progressive autonomy linked to children's participation in decision-making should be based on a gradual increase in both the responsibility and scope of such decisions. Thus, as children acquire autonomy and greater accountability and responsibility, they can be seen as partners in the process, because of their increased participation in school organisation and decision-making, becoming sovereigns of their choices, opinions, proposals, decisions, and contributions (Díaz Bórquez et al., 2019). We argue that a prerequisite for this to occur is the recognition of children as participa- tory social actors at school: the acknowledgement of children's capacity for human agency.

\section{Transforming Adults' Barrier Attitudes: Recognition of Children's Agency}

The final component whose importance we wish to emphasise is that of the human agency of children. The concept of agency relates to the capacity for human action and "encompasses a range of ideas including choice, capability, dispositions, self-critique and choice and practices" (Higgs, 2019, p. 10). Zavala Berbena and Castañeda Figueiras (2014) note that Aristotle was the first philosopher to be interested in and analyse the term from studying the ontology of human actions. He conceptualised the term as any activity oriented towards excellence: human action as an active use of reason grounded in the will to achieve goals and articulate desires whose foundation is freedom understood as relational ethics. The same authors, tracing a genealogy of the concept, note that in the Middle Ages, St. Thomas Aquinas defined agency as naturally kindly directed rational action; and already in modernity, Marx analysed the term as historically rooted and from a perspective of action-oriented not only to kindly rational action but to the transformation of the physical and social world (Zavala Berbena \& Castañeda Figueiras, 2014).

A core element of human agency is its relational nature. Developing an agentic identity and exercising agency relies on the recognition as agents by the other within the relationship (Edmonds, 2019; Erstad et al., 2021; Sutterlüty \& Tisdall, 2019; Thomas, 2007). In this regard, minoritized groups such as racialised people, women, and children have traditionally been excluded from such recognition due to non-participation in private and public decision-making (González Coto, 2012). While women's and ethnic minorities' liberation movements have made great strides forward-not in a globalised way and with much still to be done-children remain largely unrecognised as capable persons (Sutterlüty \&

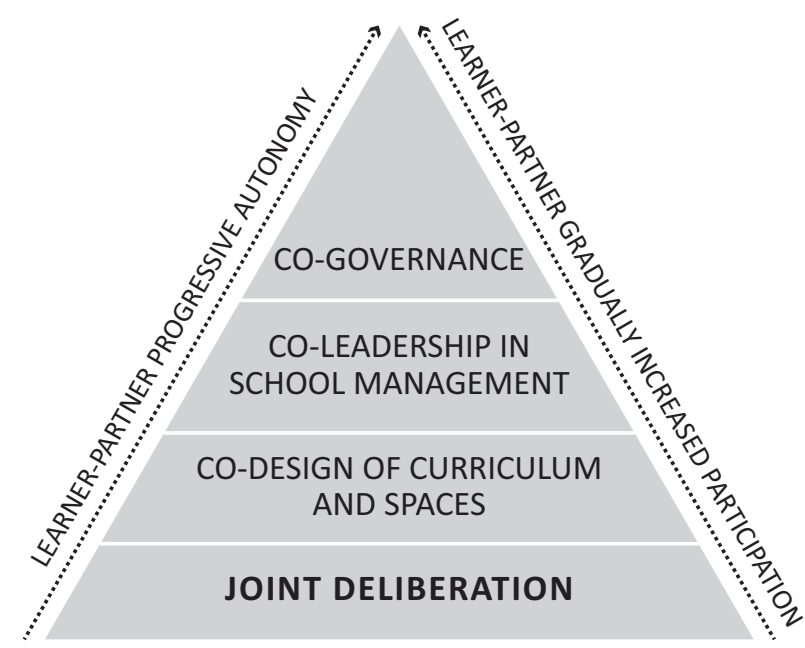

Figure 1. Learner-partner gradually increased participation following their progressive autonomy. 
Tisdall, 2019) in the asymmetrical power relations that exist within the intergenerational order (Liebel, 2018; Mühlbacher \& Sutterlüty, 2019).

As adults, we can relate to children from either enabling or limiting beliefs (Rodríguez-Moriche \& Vallejo-Jiménez, 2019). Limiting beliefs act as adult barriers to the free development of children's personality, autonomy, and sense of agency; Mead (1934, as cited in Mühlbacher \& Sutterlüty, 2019) claimed that children and adolescents would develop the capacity for autonomous, intentional, and self-directed action if and only their human agency-their condition as agents in their communities-is recognised. Undoubtedly, since the adoption of the UNCRC, significant progress has been made towards such recognition since it stipulates that children are subjects of rights and social agents. However, Gallagher (2019, p. 189) notes that "the idea that children are active social agents became a familiar mantra from the 1990s onwards," underlining that there is a yawning gap between theory and practice. Much has been written and theorised about children as capable social agents, about children's agency-although the debate is still open as to whether this agency is equal to or different from adult agency-about children's rights and their status as subjects of rights and not only as passive recipients of rights. However, according to Wall (2008), these epistemologies are not reflected in the practice because the adult gaze has not yet transcended historical adultcentrism, to which we add overprotective paternalism, and modern conceptions of childhood. These modern conceptions of childhood led to the constitution of a new representation that persists to this day. As early as 1988, Alanen asserted, citing Ariès (1962), that the construction of the modern representation of childhood took place within the framework of a bourgeois class that needed to ensure its survival and reproduction in a society whose structures were in a dramatic process of change. According to the author:

The child emerged in this context as a social and practical construct to be realized for the younger members of that particular class. It is for this project that various schemes of child care and education were developed leading to the formation of extraordinary social worlds for their inhabitants-notably the "intimate family" and the school-and consequently to the formation of a particular "habitus" as well. This product-modern childhood-was later made available for other social classes. (Alanen, 1988, p. 64)

The creation of the modern child implied the separation of the adult and infant worlds and an over-theorisation of the new construct developed around the infant stage from different disciplines.

Many efforts have been and continue to be made in the academic, political, and educational spheres to reverse this modern conception of childhood and this separation between the adult and child spheres.
We could affirm that thanks to the approval of the UNCRC and its subsequent general comments and observations, as well as to the substantial body of scientific literature on the subject, an epistemological shift on childhood as a concept has taken place, but has it reached the ontological realm? Has it brought about a genuine transformation of how we as adults relate to children? As Alanen (2012) recalls, the concept of childhood should be approached from its relational dimension, given that it is not so much a category defined by an age range as a concept defined in opposition to the terms "adult" and "adulthood."

All things considered, authors such as Liebel (2018) and Dailey and Rosenbury (2018) argue for the need to include the recognition of children's agency as a right. Liebel $(2018$, p. 24) argues that "children will only fully become subjects of rights when their human rights are also regarded as agency rights, and when their interests as people capable of acting are recognised." The same author holds that this right implies the recognition of children as capable people-an enabling belief-and the creation of the material conditions for them to be able to use them. On the other hand, Dailey and Rosenbury (2018) uphold that children's rights to agency are not synonymous with advocating for their rights to autonomy. Children can participate in the decision-making while being dependent on adults from their heteronomous condition. As Freeman (2006, p. 90) points out, "rights are important because those who have them can exercise agency." Thus, the exercise of rights, the recognition of the other's agency, and one's sense of agency are mutually reinforcing; they cannot exist in isolation from the others.

Undoubtedly, schools are ideal space-time locations for creating such conditions insofar as adults, who are ultimately responsible for children's welfare and school organisation, assume that "agents are decision-makers. They are persons who can negotiate with others, who can alter relationships and decisions, who can shift social assumptions and constraints. And there is now clear evidence that even the youngest amongst us can do this" (Freeman, 2011, p. 90). We regard the recognition of children's agency as the foundation of their inclusion as partners in schools. This recognition entails a series of enabling beliefs on the part of adults that remove those barrier attitudes that prevent children from participating as partners and stakeholders in their school communities. These enabling beliefs necessarily involve recognizing children as subjects of rights, particularly as having the right to participate in decision-making in matters that affect them, which will gradually increase as they become progressively autonomous. Figure 2 shows the interactions of these three elements in the configuration of a school as an inclusive educational democratic community or fellowship. The figure provides a preliminary outline of how children's participation in decisionmaking could be progressively implemented in different school dimensions and in accordance with their progressive autonomy. 


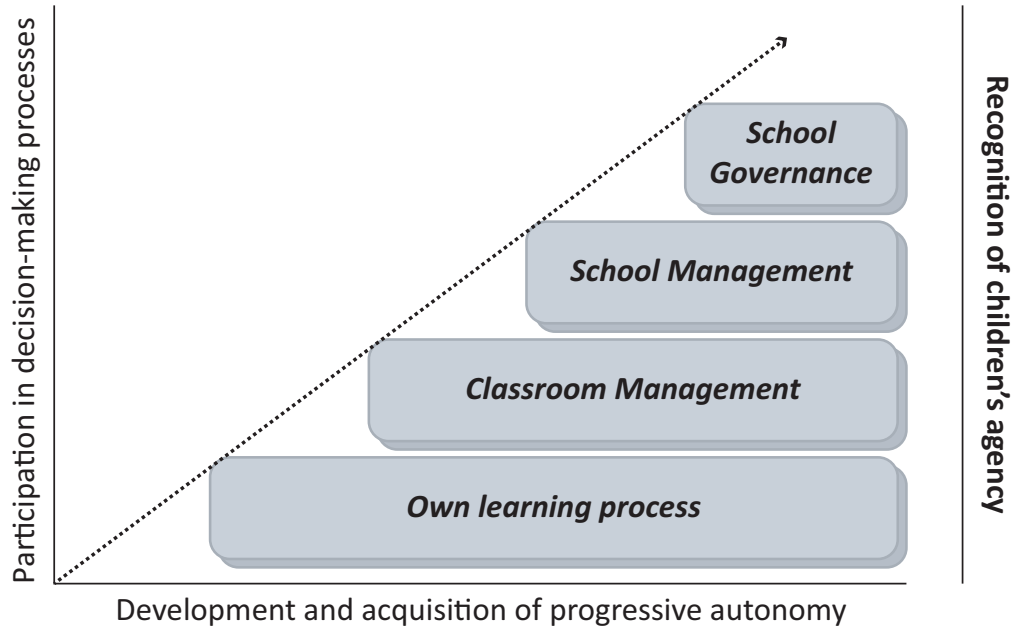

Figure 2. Schools as inclusive educational democratic communities or fellowships.

\section{Final Remarks}

There is a need for an epistemological broadening of the concept of "inclusive education"; an epistemological broadening that integrates the meaning of "reaching to all learners" with the inclusion of children as learner-partners, that is, as participatory social actors, valid interlocutors, and active members at school, turned into inclusive educational democratic communities or fellowships. To this end, the three elements outlined in this article pose that (a) children's participation in the decision-making should be considered, (b) according to their progressive autonomy and (c) through the recognition of their agency. Otherwise, children may not be acknowledged as learners-partners and concepts such as educational inclusion and children's agency will remain empty aphorisms.

We propose a gradual increase in children's participation in decision-making, in their role as learners-partners following their progressive autonomy, with the following sequence:

1. Joint deliberation with teachers and other school staff: At this first level, children are recognised as agents capable of making decisions in co-responsibility with their peers and with adults at the group-class meso-level. This allows for a first step towards decision-making on aspects linked to classroom management or activities in their free time. Examples of this first foray into decisionmaking would be associated with the definition of rules and sanctions, distribution of the school timetable or leisure time activities.

2. Co-design of the curriculum and spaces: This second level entails greater involvement in decisionmaking from the children's commitment to their learning process and responsibility at the individual micro-level and the management of spaces and collective responsibility at the meso-level of the group-class. From this recognition of children's agency, children make decisions about their learning processes; they define their objectives both individually and collectively, and the time they will devote to the subject to achieve them. Children can also make proposals regarding the use of spaces and their distribution, adapted to their individual and shared needs.

3. Co-leadership in the school management: Achieving a level of participation in co-leadership and management requires prior experience of the responsibility involved in decision-making on relevant and binding issues. At this level, children participate in teacher and management coordination meetings and make decisions on issues directly affecting them at a stage halfway between the meso-level of the group-class and the macro-level of the school.

4. Co-governance: Co-governance implies that children participate directly in the school's management. This co-governance takes place on an equal footing with the management team, where children are informed and consulted and proactive in management, make their proposals, and their voice and vote are given equal consideration to those of adults.

This sequence is grounded on the progressively implicative action of children within the school community. This participation in decision-making in school organisations must respond to the principle of progressive autonomy, an autonomy based on the acquisition of knowledge, skills, and personal responsibility and for others through the construction of a moral personality that combines the need to care for the "I" with the need to place the "we" at the centre of educational action.

Thus, adults and children will be able to see and recognise each other within the intergenerational relationship and the educational exercise from an ethics of care that, far from pretending to build symmetrical relationships, positions the child as an agent, based 
on their capabilities and possibilities, recognising their knowledge and experiences, including, and validating them. Thus, children receive the guidance and support required for the harmonious development of their personalities and their moral conscience, guiding principles of education.

Including children as partners in a school transformed into an inclusive educational democratic community or fellowship will not be possible if a subjective children's rights approach is not incorporated into teacher training, which ought to include children's rights of agency. In this respect, the training deficit of teachers is apparent, and there is an urgent need for discussion and the incorporation of these elements in the curricula of trainee teachers and the in-service training plans of active teachers. As Tonucci (Fundación La Caixa, 2021) encourages us to reflect, can a school be considered legal if it does not listen to children's voices? To which we add, can a school be considered legal if it does not heed children's voices and consider them as participatory social actors?

Some believe that schools need to be better resourced to enable their democratisation. However, what do they mean by resources: more staff, more technological equipment, more funding? The experience of educational institutions with small budgets and with a majority of children at risk of social exclusion, which have become genuinely democratic and inclusive thanks to the commitment and determination of the teaching staff, shows us that it is the change in the adult perspective that is essential, and not so much the need for infinite resources. In this sense, it is also crucial for schools to have a stable workforce since any project aiming to be sustained and sustainable over time requires implicated and committed personnel to carry it out and keep it alive, in constant review, evaluation and improvement.

There is no less critical concern about how specific political colours condition the viability of participatory and inclusive educational projects. This is an ideological approach whose logic responds to the polarisationintentional or not-of democracies, becoming increasingly partisan and illiberal by the day. The social division we are experiencing is much related to and triggered by political colours and bigotry. Contributing to this polarisation by defending or criticising one or another political model gives rise to an ideological bias that transmits the idea that certain parties or ideologies are more conducive to citizen participation and the inclusion of children as capable social agents than others. The issues tackled in this article should be of interest to anyone who considers themselves a democrat, regardless of whether they are more or less conservative, more or less liberal, more or less progressive.

Finally, we are confident that this approach could also contribute to addressing SDGs no. 4 and no. 16 . Ensuring inclusive education requires the inclusion of children as learners and as partners in communities that prepare for democracy and are lived democrati- cally. Moreover, the consolidation of democratic institutions can be strengthened if children know that they are part of and responsible members of these institutions from a very early age. The present and alarming discredit on democratic systems could be turned around if children are recognised as having moral, transformative, and action agency. Schools are ideal spaces for such purposes, provided that adults commit themselves to them.

\section{Acknowledgments}

This article is published in the framework of the R\&D project Childhood and Participation: Diagnosis and Proposals for an Active and Inclusive Citizenship in the Community, Institutions and Governance (RTI2018-098821-B-I00; https://www.ub.edu/infanciay participacion) funded by the Spanish Ministry of Science and Innovation, the European Regional Development Fund, and the Spanish State Research Agency.

\section{Conflict of Interests}

The author declares no conflict of interests.

\section{References}

Alanen, L. (1988). Rethinking childhood. Acta Sociologica, 31(1), 53-67. https://doi.org/10.1177/0001699 38803100105

Alanen, L. (2012). Moving towards a relational sociology of childhood. In R. Braches-Chyrek, C. Röhner, \& H. Sünker (Eds.), Kindheiten. Gesellschaften: Interdisziplinäre Zugänge zur Kindheitsforschung [Childhoods. Societies: Interdisciplinary approaches to childhood research] (1st ed., pp. 21-44). Verlag Barbara Budrich. https://doi.org/10.2307/j.ctvd7w8xd

Andreasen Lysgaard, J., \& Simovska, V. (2016). The significance of "participation" as an educational ideal in education for sustainable development and health education in schools. Environmental Education Research, 22(5), 613-630. https://doi.org/ 10.1080/13504622.2015.1029875

Apple, M., \& Beane, J. (Eds.). (2007). Democratic schools. Lessons in powerful education (2nd ed.). Heinemann.

Ariès, P. (1962). Centuries of childhood. Penguin.

Charter of fundamental rights of the European Union. (2000). Official Journal of the European Union, C 364/1. https://www.europarl.europa.eu/charter/ pdf/text_en.pdf

Dailey, A. C., \& Rosenbury, L. A. (2018). The new law of the child. The Yale Law Journal, 127, 1448-1537. https://heinonline.org/HOL/LandingPage?handle= hein.journals/ylr127\&div=32\&id=\&page=

Day, L., Percy-Smith, B., Ruxton, S., McKenna, K., Redgrave, K., Ronicle, J., \& Young, T. (2015). Evaluation of legislation, policy, and practise on child participation in the European Union. European Commission. https://op.europa.eu/en/publication- 
detail/-/publication/3f3c50b2-6a24-465e-b8d174dcac7f8c42

De Haro, R., Arnaiz, P., Alcaraz, S., \& Caballero, C. (2019). Escuchar las voces del alumnado para construir la inclusión y la equidad educativa: Diseño y validación de un cuestionario [Listening to students' voices to build inclusion and educational equity: Design and validation of a questionnaire]. Multidisciplinary Journal of Educational Research, 9(3), 258-292. https:// doi.org/10.17583/remie.2019.4613

Díaz Arce, S. R. (2019). Infancia, derechos humanos y ciudadanía [Childhood, human rights, and citizenship]. Revista Latinoamericana de Derechos Humanos, 30(2). https://doi.org/10.15359/rldh.30-2.3

Díaz Bórquez, D., Bozo Carrillo, N., \& Contreras Shats, N. (2019). Calidad de la participación infantil en la política local de infancia chilena [Quality of children's participation in Chilean childhood local policy]. Revista Trabajo Social, 91, 1-17. https://doi.org/ 10.7764/rts.91.1-17

Echeita Sarrionandía, G., \& Ainscow, M. (2011). La educación inclusiva como derecho: Marco de referencia y pautas de acción para el desarrollo de una revolución pendiente [Inclusive education as a right: Framework and guidelines for action for the development of a pending revolution]. Tejuelo: Didáctica de la Lengua y la Literatura. Educación, 12, 26-46. https://tejuelo. unex.es/article/view/2497

Edmonds, R. (2019). Making children's "agency" visible: Towards the localisation of a concept in theory and practice. Global Studies of Childhood, 9(3), 200-211. https://doi.org/10.1177/2043610619860994

Erstad, O., Miño, R., \& Rivera-Vargas, P. (2021). Prácticas educativas para transformar y conectar escuelas y comunidades [Educational practices to transform and connect schools and communities]. Comunicar, 66, 9-20. https://doi.org/10.3916/C66-2021-01

Esteban Tortajada, M. B., \& Novella Cámara, A. M. (2018). Jóvenes, participación y democracia: Retos propositivos expuestos por la juventud [Youth, participation and democracy: Propositional challenges exposed by young people]. RELAPAE, 9, 110-124. http://revistas. untref.edu.ar/index.php/relapae/article/view/228

European Commission. (2011). An EU agenda for the rights of the child. https://eur-lex.europa.eu/legalcontent/EN/TXT/PDF/?uri=CELEX:52011DC0060\& from $=\mathrm{EN}$

Farré Riera, L. (2021). El reconeixement de les veus de l'alumnat per a la reflexió de la pràctica educativa a secundària [The recognition of students' voices for the reflection of educational practice in secondary school] (Doctoral dissertation, Universitat de VicUniversitat Central de Catalunya). Tesis Doctorals en Xarxa. https://84.88.27.106/handle/10803/672284

Feu Gelis, J., \& Torrent Font, A. (2018). Democracia y participación: La voz (silenciada) de los alumnos [Democracy and participation: The (silenced) voice of pupils]. Voces de la Educación, 2018(1), 43-51. https://www.revista.vocesdelaeducacion.com.mx/ index.php/voces/article/view/149

Fielding, M. (2011). La voz del alumnado y la inclusión educativa: Una aproximación democrática radical para el aprendizaje intergeneracional [Student voice and inclusive education: A radical democratic approach to intergenerational learning]. Revista Interuniversitaria de Formación del Profesorado, 25(1), 31-61. https://www.redalyc.org/pdf/274/ 27419147003.pdf

Fielding, M. (2012). Beyond student voice: Patterns of partnership and the demands of deep democracy. Revista de Educación, 359, 45-65. https://doi.org/104438/1988-592X-RE-2012-359-195

Freeman, M. (2006). What's wrong with children's rights. Harvard University Press.

Freeman, M. (2011). The value and values of children's rights. In J. Williams (Ed.), The human rights of children. From vision to implementation ( $1^{\text {st }}$ ed.) (pp. 21-36). Routledge. https://doi.org/10.4324/97813 15557007

Fundación La Caixa. (2021, June 7). El profesorado según Frato [Video]. https://www.youtube.com/watch?v= RNOmFm72AnE

Gallagher, M. (2019). Rethinking children's agency: Power, assemblages, freedom and materiality. Global Studies of Childhood, 9(3), 188-199. https:// doi.org/10.1177/2043610619860993

González Coto, M. (2012). La agencia de la niña y el niño en la condición pre-ciudadana [Agency childhood in the pre-citizen condition]. Actualidades Investigativas en Educación, 12(2), 1-19. https://doi.org/ 10.15517/AIE.V12I2.10287

Higgs, J. (2019). Appreciating practice wisdom. In J. Higgs (Ed.), Practice wisdom (pp. 3-14). Brill Sense. https:// doi.org/10.1163/9789004410497_001

Honneth, A. (2012). The I in we: Studies in the theory of recognition. Polity Press

Honneth, A., \& Margalit, A. (2001). Recognition. Proceedings of the Aristotelian Society, 75, 111-139. https:// www.jstor.org/stable/4107035

Janta, B., Bruckmayer, M., da Silva, A., Gilder, L., Culora, A., Cole, S., Leenders, E., Schuurman, M., \& HaggerVaughan, A. (2021). Study on child participation in EU political and democratic life. European Commission. https://ec.europa.eu/info/sites/default/files/child_ participation_final_raport_revised_28.04.2021_ final_web_pdf.pdf

Lansdown, G. (2005). The evolving capacities of the child. Innocenti Research Centre; UNICEF; Save the Children. https://www.unicef-irc.org/publications/384the-evolving-capacities-of-the-child.html

Liebel, M. (2015). Sobre el interés superior de los niños y la evolución de las facultades [On the best interest of the children and the evolving capacities]. Anales de la Cátedra Francisco Suárez, 49, 43-61. https://doi.org/ 10.30827/acfs.v49i0.3277

Liebel, M. (2018). Welfare or agency? Children's inter- 
ests as foundation of children's rights. The International Journal of Children's Rights, 26(4), 597-625. https://doi.org/10.1163/15718182-02604012

Liebel, M. (2019). Janusz Korczak, los derechos y el protagonimo de la infancia [Janusz Korczak, children's rights and protagonism]. Revista de Educación Social, 28, 176-195. https://eduso.net/res/revista/ 28/miscelanea/janusz-korczak-los-derechos-y-elprotagonismo-de-la-infancia

Mèlich, J. C., \& Bárcena, F. (1999). La palabra del otro: Una crítica del principio de autonomía en educación [The word of the other: A critique of the principle of autonomy in education]. Revista Española de Pedagogía, 57(214), 465-483. https://www.jstor. org/stable/23765223

Messiou, K. (2018). Using primary school children's voices to promote inclusive education. Voces de la Educación, 1, 11-27. https://dialnet.unirioja.es/ servlet/articulo?codigo $=6577754$

Molins i Paronella, A. (2020). La omnipotencia infantil: Un problema bioético. La necesidad y urgencia de repensar la educación en el marco de la ética del cuidar [Children's omnipotence: A bioethical issue. The need and urgency to rethink education within the framework of care ethics]. Revista de Bioética y Derecho, 49, 93-106. https://scielo.isciii.es/ scielo.php?script=sci_arttext\&pid=S1886-58872020 000200007

Moosa-Mitha, M. (2005). A difference-centred alternative to theorization of children's citizenship rights. Citizenship studies, 9(4), 369-388. https://doi.org/ 10.1080/13621020500211354

Moreno Gómez, I., Lleonart Forradellas, P., Carranza GilDolz, M., Esteban Tortajada, M. B., \& Novella Cámara, A. M. (in press). Inclusión de niños, niñas y adolescentes para transformar. Experiencias de participación de las infancias en proyectos y servicios del Instituto de Educación Municipal (Ayuntamiento de Barcelona) [Inclusion of children and adolescents for change. Experiences of children's participation in projects and services of the Municipal Education Institute (Barcelona City Council)]. In M. R. Belando Montoro (Ed.) Participación cívica en un mundo digital [Civic participation in a digital world]. Dyckinson.

Mühlbacher, S., \& Sutterlüty, F. (2019). The principle of child autonomy: A rationale for the normative agenda of childhood studies. Global Studies of Childhood, 9(3), 249-260. https://doi.org/10.1177/ 2043610619860999

Olufisayo John-Akinola, Y., Gavin, A., Elizabeth O'Higgins, S., \& Nic Gabhainn, S. (2014). Taking part in school life: Views of children. Health Education, 114(1), 20-42. https://doi.org/10.1108/HE-02-2013-0007

Organisation of Ibero-American States for Education, Science and Culture. (2010). Metas educativas 2021: La educación que queremos para la generación de los bicentenarios [Education goals 2021: The education we want for the generation of the bicentenarians]. https://oei.int/publicaciones/metas-educativas2021-la-educacion-que-queremos-para-lageneracion-de-los-bicentenarios-documento-final

Rodríguez-Moriche, M. P., \& Vallejo-Jiménez, S. I. (2019). Nuevos horizontes de ocio y participación infantil: Construyendo ciudadanía desde los intereses y necesidades de los niños, niñas y adolescentes (NNA) [New horizons for children's leisure and participation: Building citizenship based on the interests and needs of children and adolescents]. In R. A. Alonso, M. Sáenz de Jubera Ocón, \& E. Sanz Arazuri (Eds.), Ocio y participación social en entornos comunitarios [Leisure and social participation in community settings] (pp. 213-233). Universidad de La Rioja. https:// dialnet.unirioja.es/servlet/articulo?codigo $=6817374$

Romanian Children's Board, Children and Experts From the EU. (2019). Bucharest EU children's declaration. UNICEF Romania. https://www.unicef.org/romania/ bucharest-eu-childrens-declaration

Santana Ramos, E. M. (2014). Las claves interpretativas del libre desarrollo de la personalidad [Interpretative keys of the free development of personality]. Cuadernos Electronicos de Filosofia del Derecho, 29, 99-113. https://accedacris.ulpgc.es/handle/10553/56594

Sañudo, M., \& Susinos, T. (2018). ¿Quién toma la palabra en la escuela? ¿Quién escucha? Preguntas pertinentes desde la práctica reflexiva [Who speaks at school? Who listens? Relevant questions from the reflexive practice approach]. Revista Latinoamericana de Educación Inclusiva, 12(1), 79-94. https:// docplayer.es/140755315-Revista-latinoamericanade-educacion-inclusiva.html

Simovska, V. (2007). The changing meanings of participation in school-based health education and health promotion: The participants' voices. Health Education Research, 22(6), 864-878. https://doi.org/10.1093/ her/cym023

Simovska, V. (2011). Case study of a participatory health-promotion intervention in school. Democracy and Education, 20(1), Article 4. https:// democracyeducationjournal.org/home/vol20/iss1/4

Sutterlüty, F., \& Tisdall, E. K. M. (2019). Agency, autonomy and self-determination: Questioning key concepts of childhood studies. Global Studies of Childhood, 9(3), 183-187. https://doi.org/10.1177/ 2043610619860992

Thomas, N. (2007). Towards a theory of children's participation. International Journal of Children's Rights, 15, 199-218. https://doi.org/10.1163/092755607 X206489

Thomas, N. (2012). Love, rights and solidarity: Studying children's participation using Honneth's theory of recognition. Childhood, 19(4), 453-466. https:// doi.org/10.1177/0907568211434604

UNESCO. (2001). The open file on inclusive education. https://www.scirp.org/(S(351jmbntvnsjt1 aadkposzje))/reference/ReferencesPapers.aspx? ReferencelD=932939 
UNESCO. (2005). Guidelines for inclusion: Ensuring access to education for all. https://unesdoc.unesco. org/ark:/48223/pf0000140224

UNESCO. (2008). Inclusive education: The way of the future [Reference document]. http://www.ibe. unesco.org/fileadmin/user_upload/Policy_Dialogue/ 48th_ICE/CONFINTED_48-3_English.pdf

UNESCO. (2017). A guide for ensuring inclusion and equity in education. https://unesdoc.unesco.org/ ark:/48223/pf0000248254

UNESCO, \& Ministry of Education and Science Spain. (1994). Salamanca statement and framework for action on special needs education (ED-94/WS/18). https://www.european-agency.org/sites/default/ files/salamanca-statement-and-framework.pdf

United Nations. (1948). Universal declaration of human rights. United Nations General Assembly.

United Nations. (1989). Convention on the Rights of the Child: Assembly resolution 44/25 of 20 November 1989. https://www.ohchr.org/EN/professional interest/pages/crc.aspx

United Nations. (2009). General comment no. 12 on the right of the child to be heard (CRC/C/GC/12 20 July 2009). https://undocs.org/en/CRC/C/GC/12

United Nations. (2015). Transforming our world: The
2030 agenda for sustainable development. UN Publishing. https://sustainabledevelopment.un.org/ content/documents/21252030\%20Agenda\%20for\% 20Sustainable\%20Development\%20web.pdf

Uriarte, C. (2013). La cuestión de la responsabilidad en el derecho penal juvenil [The liability issue in juvenile criminal law]. Los Sentidos del Castigo, 141. http://dt.csic.edu.uy/adjuntos/produccion/166_ academicas_academicaarchivo.pdf\#page $=141$

Van Manen, M. (2016). The tact of teaching: The meaning of pedagogical thoughtfulness. Routledge.

Wall, J. (2008). Human rights in light of childhood. The International Journal of Children's Rights, 16(4), 523-543. https://doi.org/10.1163/157181808X312 122

Zavala Berbena, M. A., \& Castañeda Figueiras, S. C. (2014). Fenomenología de agencia y educación. Notas para el análisis del concepto de agencia humana y sus proyecciones en el ámbito educativo [Phenomenology of agency and education. Notes for analyzing the concept of human agency and its projections into the sphere of education]. Magister, 26(2), 98-104. https://doi.org/10.1016/S02126796(14)70024-6

\section{About the Author}

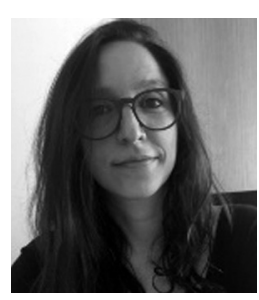

Marta B. Esteban is a researcher in the Education and Society Programme at the University of Barcelona. Her research and studies focus on child and adolescent participation, analysing the recognition of their capacity for agency as part of the intergenerational relationships between adults, adolescents, and children. She holds a master's degree in educational research from the Autonomous University of Barcelona and a master's degree in education in values and citizenship from the University of Barcelona. She is also a primary education teacher. 